It is now certain that Brahe, whilst at Wandesbeck, or Wandesburg, near Hamburg, sat to a painter, for here we have evidence in a book published at Copenhagen, in 1668 , that King Frederick IIJ. had that picture and that it was dated Vandesbechi, 1597; and moreover, that that portrait had an emblem upon it, which, from the motto, was presumably very like that on mine, but the position and the words of the motto differing, the motto and also the inscription on King Frederick's portrait being below the emblem, whilst on mine the motto is on a ribbon or label wound round the pyramid, and the inscription is on the other side of the picture. In King Frederick's the emblem consisted of a pyramid with some kind of covering ("sub pyramide tegumento quodam cooperta"), and so it is in mine. That wind, fire, and water were also represented in that emblem, as in mine, is clear from the words "ventus, ignis, et unda" in the motto, which are precisely the words employed in mine, the oniy difference in the two cases being that in the king's there is the word "fremat," instead of "strepat" as on mine. In my portrait the year 1597 is inferred from the inscription saying "Anno 50 completo," Brahe being fifty years old on December 13. I596. By a careful examination of Brahe's Latin Life by Gassendi, 1656 , I found that Brahe wrote a reinarkable poem addressed to Ranzovius, in which the words "exilium in patria" occur ; and as he stayed at Ranzovius's from the end of October, I 597, I conjectured (P'roceedings of Lit. and Phil. Soc. of Manchester, October 31,1876 ) that my portrait was painted between that date and his rext birth-day (December I3, I597), a suppositicn confirmed by IIerr Fris pointing out that the lost picture of King lrederick's is dated at Wandesburg (Vandesbechi).

That mine is no copy of that picture is manifest from the differences which the notice in the "Inscriptiones Haffnienses" has enabled me to point out. My conjecture is that Brahe sent his portrait to King Frederick, who is expressly absolved by Brahe from the blame of Brahe's expulsion from Denmark, anil that he advisedly wrote "pristine libertati" instenil of "libertati desiderata" as on mine; and further I have litule donbt that the same or ist painted buth pictures.

I have examined the portraits in the print room of the British Museum as well as the oil painting at the Royal Society, and have taken much pains to ascertain the existence of any other portrait than mine representing Bahe later than I 587 ; ten years earlier than mine. That it does not agree with the engraving after Gumperin's portrait is no proof whatever that mine is not a good representation of him in his fifty. first year, when we consider how much a man's features change in the ten years between forty-one and fifty-one, and moreover Brahe may have been in the meantime to the Promontory of Noses for a fresh one. But whatever be the renconableness of these conjectures, it is almost certain that he sat twice at Wandesburgh to this portrait painter, and that one of these portraits was considered worthy of a place in the king's library. SAMUEL Crompron

Manchester

\section{Lumiere Cendrée}

SCHKÖLER pointed out that it is towards the third day of the new moor that the ashy light has the most intensity and that it is stronger before thic new moon than after.

Schroter's explanation is that during the waning of the moon the ashy light is stronger because the moon is enlightened bythe continents of Asia, Africa, and Europe, but after the new moon by the Atlantic and Pacific Oceans.

Godfray in his $\Lambda$ stronomy says :-Supposing this difference to exist, and this explanation to be the correct one, the phenomenon must be just reversed in China and Japan.

Has anything been done to test the accuracy of Schröter's theory? If it is correct the ashy light cannot present the same appearance to an astronomer in New York, because there would be a greater proportion of reffecting surface in the hemisphere of the earth turned towards the moon in the one case than the other.

Schröter, I believe, found that the ashy light was stronger in autumn than in spring. This cannot be accounted for by his explanation, for the distribution of land and water remains the same.

I shall be obliged to any of your correspondents who can tell me where there are any records of observations on this subject.

4, Buccleuch Road,. Dulwich, October I
Lightring Conductors

IN a paper on lightning conductors, communicated by us to the Fournal of the Society of Telegraph Engineers, we gave at full length our reasons for believing that the wire cage first suggested some years ago, and recently proposed by Prof. Clerk Maxwell, as a protection agrainst lightning, would not act as a complete protection, since, although there is no resultant force inside a closed conductor due to exterior statical electrification, experiment shows the existence of such a force when electric currents are passing either near or through a closed conductor. The recent case of deaths by lightning in a mine, communicated to the Asiatic Society of Bengal, on A pril 4 of this year, by J. J. Whitty, Esq., superintendent of the Kurhurbari Collieries, Giridhi, India, appears to add experimental proof to the reasoning advanced in our paper. Mr. Whitty says :- "The mine is a shallow one, worked by levels driven on the side of a flattopped hill, only twenty fect from the surface, which is, therefore, the thickness of rock abuve the coal-seam. The working.face where the accident occurred is about $\mathbf{I} 30$ feet from the opening. There were a number of miners in the drift at the time. Those near the entrance were unaffected. The two who were killed (a man and a woman) were at the working-face in adjoining galleries, separated by about twelve feet of cual. A young sál tree, standing as nearly as possible over the position of the accident, was slightly damaged, arc, in the grourd at its base a hole, ahout one inch in diameter, seeined to have been formed by lightning. The little hill, or ylnteau, in which the mine is situated is one of a small irregular group in the centre of the coal field, about 200 feet high. It is formed of the coal-measure sandstone. The drainare is thorough, and the mine was quite iry. From the presence of the workmen the sidcs of the gallery and the air in it wcre probably damper than the rock. The tree or other vegetation on the hill is scanty. On the dny of the accilent 0.96 inches of rain fell."

It wonld therefore appear that the two penple who were killed were practically entirely surounded by a partial conductor in crinnection with the earth. It will no doubt be objected that twenty feet thickiess of coal-measure sandstone, even when damp on the surface, is not a good closed conductor, but we thirk it is certainly as good a protection as would be afforded by the wires I'rof. Clerk Maxwell proposes to lead merely along the edges of a building.

JOIN P'ERRY

The Imperial College of linginecring, Tokito, Japan, August 6

\section{Electric Lighting}

I HAVE examined the patent (No. I0,919, November 4, 1845, Liward Augustin King) which Prof. Mattieu Williams drew attention to in NATURE, vol. xvi. p. 459 , as anticipating the invention of Lodighin's electric wick, and I think Lodighin bas been clearly forestalled in principle, the practical dotails alone being clifferent in the two cases.

I do not think, however, that Mr. King's palcnt includes Kosluff's improvement, whatever value may attach to the latter. I think it is very plain that porcelain is cmployed in King's patent merely as an insulating bar to connect the two forceps rigidly together without shunting any of the current between them past the carbon.

West Croydon, October 2

J. MUNRO

\section{Caterpillars}

LAS'T year (NATURE, vol. xy. p. 7) I cummunicated the result of some txperiments on the caterpillars of Pieris brassica from which it appeared that, when these are artificially converted from succincti into suspensi by cutting the loop before the exclusion of the chrysalis, a certain number (a third or fourth of the whole succeed in attaching themselves to the silk by the hooks in the tail of the chrysalis in the manner of the true suspertsi. I have repeated the experiment this year with a like result, and $I$ bave also had the satisfaction of witnessing the process of successful exclusion, and comparing it with that of the chrysalis of Vanessa motice. The metbod is essentially the same, except that the rapid and assured precision with which the Vanessa chrysalis thrusts up its tail and lays hold upon the silk, is replaced in Pieris by long and laborious efforts, as if the tail were just a little too short to reach the silk.

I have likewise made similar experiments with another of the 